\title{
Respiratory functional status after conventional and minimally invasive aortic valve replacement surgery - a propensity score analysis
}

\author{
Jarosław Stoliński ${ }^{1}$, Robert Musiał², Dariusz Plicner ${ }^{1}$, Kamil Fijorek $^{3}$, Michał Mędrzycki ${ }^{1}$, Janusz Andres ${ }^{2}$, \\ Bogusław Kapelak ${ }^{1}$ \\ ${ }^{1}$ Department of Cardiovascular Surgery and Transplantation, Jagiellonian University, Pope John Paul II Krakow Specialist \\ Hospital, Kraków, Poland \\ ${ }^{2}$ Department of Anaesthesiology and Intensive Care, Jagiellonian University, Pope John Paul II Krakow Specialist Hospital, \\ Kraków, Poland \\ ${ }^{3}$ Department of Statistics, University of Economics, Kraków, Poland
}

Kardiochirurgia i Torakochirurgia Polska 2017; 14 (1): 5-9

\begin{abstract}
Introduction: Reports describing respiratory function of patients after conventional or minimally invasive cardiac surgery are infrequent.

Aim: To compare pulmonary functional status after conventional (AVR) and after minimally invasive, through right anterior minithoracotomy, aortic valve replacement (RT-AVR).

Material and methods: This was an observational analysis of 212 patients scheduled for RT-AVR and 212 for AVR between January 2011 and December 2014 selected using propensity score matching. Respiratory function based on spirometry examinations is presented.

Results: Hospital mortality was $1.4 \%$ in RT-AVR and $1.9 \%$ in AVR $(p=0.777)$. Predicted mortality (EuroSCORE II) was 3.2 $\pm 1.1 \%$ in RT-AVR and $3.1 \pm 1.6 \%$ in AVR $(p=0.298)$. Mechanical ventilation time in intensive care unit (ICU) was $7.3 \pm 3.9 \mathrm{~h}$ for RT-AVR and $9.6 \pm 5.5 \mathrm{~h}$ for AVR patients ( $p<0.001)$. Seven days and 1 month after surgery, the reduction of spirometry functional tests was greater in the AVR group than in the RT-AVR group $(p<0.001)$. Three months after surgery, all spirometry parameters were still reduced and had not returned to preoperative values in both RT-AVR and AVR groups. However, the difference in spirometry values was no longer statistically significant between RT-AVR and AVR groups. Presence of chronic obstructive pulmonary disease and conventional AVR surgical technique were associated with lower values of spirometry parameters after surgery in linear median regression.

Conclusions: Respiratory function based on spirometry examinations was less impaired after minimally invasive RT-AVR surgery in comparison to conventional AVR surgery through median sternotomy.
\end{abstract}

Key words: minimally invasive, aortic valve, respiratory function.

\section{Streszczenie}

Wstęp: Stan czynnościowy układu oddechowego pacjentów po klasycznej oraz małoinwazyjnej operacji wymiany zastawki aortalnej nie był dotychczas wystarczająco badany.

Cel: Porównanie stanu czynnościowego układu oddechowego po klasycznej (AVR) oraz małoinwazyjnej, poprzez minitorakotomię prawostronną (RT-AVR), operacji wymiany zastawki aortalnej.

Materiał i metody: W badaniu wzięło udział 212 pacjentów zakwalifikowanych do RT-AVR oraz 212 do AVR, operowanych między styczniem 2011 a grudniem 2014 r. Grupy dobrano, stosując propensity score matching. Funkcję układu oddechowego analizowano na podstawie badań spirometrycznych.

Wyniki: Śmiertelność szpitalna w grupach po RT-AVR oraz AVR wynosiła odpowiednio $1,4 \%$ oraz $1,9 \%(p=0,777)$. Śmiertelność przewidywana (EuroSCORE II) wynosiła 3,2 $\pm 1,1 \%$ po RT-AVR oraz $3,1 \pm 1,6 \%$ po AVR $(p=0,298)$. Mechaniczna wentylacja płuc na oddziale intensywnej opieki po RT-AVR oraz AVR trwała odpowiednio 7,3 $\pm 3,9$ oraz 9,6 $\pm 5,5$ godziny $(p<0,001)$. Po tygodniu oraz miesiącu od operacji większą redukcję wyników spirometrii stwierdzono u pacjentów po AVR niż RT-AVR $(p<0,001)$. Trzy miesiące po operacji wyniki testów spirometrycznych były wciąż obniżone w porównaniu z wartościami sprzed operacji w obu grupach, jednak różnice pomiędzy grupami nie były już istotne statystycznie. Przewlekła obturacyjna choroba płuc oraz klasyczna technika operacji AVR były czynnikami ryzyka niższych wyników testów spirometrycznych w zastosowanym modelu regresji. Wnioski: Po operacji wymiany zastawki aortalnej funkcja układu oddechowego oceniana na podstawie testów spirometrycznych pogorszyła się w mniejszym stopniu u pacjentów, którzy byli poddani operacji małoinwazyjnej, w porównaniu z osobami operowanymi klasycznie przez sternotomię pośrodkową.

Słowa kluczowe: małoinwazyjne operacje, zastawka aortalna, funkcja oddechowa.

Address for correspondence: Jarosław Stoliński MD, PhD, Department of Cardiovascular Surgery and Transplantation, Jagiellonian University, Pope John Paul II Krakow Specialist Hospital, 80 Prądnicka St, 31-202 Kraków, Poland, phone: +48 607916 625, e-mail: jstolinski@gmail.com Received: 20.12.2016, accepted: 15.02.2017. 


\section{Introduction}

A right anterior minithoracotomy allows entry to the thoracic cavity without splitting the sternum and has been adopted by different cardiac surgery centres to perform minimally invasive aortic valve replacement with very good results [1]. Reports describing the pulmonary function of patients after conventional or minimally invasive cardiac surgery are infrequent $[2,3]$.

\section{Aim}

The aim of this study is to compare pulmonary function in patients who underwent elective aortic valve replacement surgery through a right anterior minithoracotomy (RT-AVR) with the results from a control group for which aortic valve replacement was performed by a standard median sternotomy approach (AVR).

\section{Material and methods Study design}

The study was performed in accordance with the Declaration of Helsinki and with the consensus guidelines expressed by the STROBE statement [4]. Approval from the Institutional Review Board and informed consent from patients were obtained and analysis of patients who had undergone aortic valve replacement surgery was conducted. It was an observational study of 221 consecutive patients who underwent RT-AVR and 316 who underwent AVR surgery between January 2011 and December 2014 at our institution.

In this study, we focused on respiratory function after aortic valve replacement using both techniques. All the data, including preoperative, in-hospital and post-discharge outcomes were prospectively collected. Patients eligible for study enrolment were those who required isolated aortic valve replacement. We excluded patients who had undergone redo surgery, aortic valve surgery with concomitant procedures, emergency operations due to infective endocarditis and patients with a left ventricle ejection fraction below $30 \%$. In our department those higher risk patients are preferentially operated on using the conventional median sternotomy. Contraindication for RT-AVR surgery were calcifications of the ascending aorta, right pleural adhesions and expected difficult access to the aortic valve, based on preoperative computed tomography, when more than half of the diameter of the ascending aorta was positioned on the left of the right sternal border [1]. To obtain two comparable study groups, propensity score matching (PSM) was used to alleviate differences in preoperative patient characteristics.

\section{Clinical parameters and perioperative events}

We analysed preoperative patients' characteristics, perioperative results, and respiratory function, which was studied based on spirometry examinations which were performed preoperatively (baseline values), on the seventh postoperative day, then after 1 and 3 months of follow-up. Analysed spirometry parameters were vital capacity (VC), forced expiratory volume in the first second $\left(\mathrm{FEV}_{1}\right)$ and total lung capacity (TLC). The baseline data are expressed as a percentage of predicted values. The follow-up data are presented as a percentage of preoperative values.

The time of discharge from the intensive care unit (ICU) or hospital was determined by medical judgment and the patient's suitability for discharge [5].

Hospital mortality was defined as death for any reason that occurred within 30 days of surgery or during the same hospitalisation period if it was longer than 30 days [6]. Predicted hospital mortality was estimated with EuroSCORE II and calculated using the online calculator (http://www. euroscore.org/calc.html). Prolonged ventilation time indicated the necessity to use mechanical lung ventilation for a period longer than $24 \mathrm{~h}$.

\section{Surgery}

A detailed description of the surgical technique for RT-AVR surgery has already been presented $[1,6]$. For preoperative planning of the RT-AVR surgery, patients underwent computed tomography imaging (Siemens Healthcare, Erlangen, Germany) [6]. A double lumen tracheal tube was used to allow for single lung ventilation. A cardiopulmonary bypass (CPB) was established with cannulation of the femoral vessels. The chest was entered through a $6 \mathrm{~cm}$ right anterior minithoracotomy in the third intercostal space. At the end of the surgical procedure, the double lumen tracheal tube was removed and the patient was re-intubated with a single lumen tracheal tube.

The pain management protocol was the same after conventional AVR surgery through median sternotomy and after minimally invasive RT-AVR surgery, and included metamizol (Pyralgin) $4 \times 1.25 \mathrm{~g}$ i.v. and oxycodone hydrochloride (Oxycontin) $2 \times 10-20 \mathrm{mg}$ p.o. given daily during the postoperative period.

\section{Statistical analysis}

Mean and standard deviation were used to report continuous variables, and counts with percentages to report categorical variables. The Mann-Whitney test was used to compare two independent groups of continuous variables, and for two dependent groups, the Wilcoxon signed-rank test was used. The Fisher exact test was used to compare two independent groups of categorical variables, and for two dependent groups the McNemar test was used.

A linear median regression was performed to analyse the association between the dependent variable and multiple independent variables. The estimated regression coefficients describe the change in the median of the dependent variable corresponding to a unit change in the independent variable with 95\% confidence intervals (CI) [7]. In this model, the dependent variables were values of $\mathrm{FEV}_{1}$, TLC and VC expressed as percentage change from baseline values 1 week and 3 months after surgery. The surgical technique, age, sex, presence of chronic obstructive pulmonary disease (COPD) and prolonged CPB time (> $120 \mathrm{~min}$ ) were independent variables in the model. 
The matched data set was constructed using propensity scores (PS). The PS were taken as linear predictor scores from the logistic regression model. The model included the following clinical variables: sex, age, age $>80$ years, body mass index, body mass index $>25 \mathrm{~kg} / \mathrm{m}^{2}$, bicuspid aortic valve, aortic stenosis, aortic valve area, haemoglobin concentration before surgery, haemodialysis, renal insufficiency, diabetes, COPD, EF > 40\%, hypertension, coronary artery disease, peripheral vascular disease, cerebrovascular disease, history of atrial fibrillation, NYHA class III or IV, history of myocardial infarction, and EuroSCORE II. Variables were selected before model estimation, and no statistical variable selection procedures were used. For each RT-AVR case one AVR case was paired, unless it was outside the calliper (equal to 0.25 of the standard deviation of the PS). Within the calliper we used optimal matching. The quality of matching was judged by the standardized differences.

All statistical analyses were performed using R 3.0 [8].

\section{Results}

After PSM there were 212 RT-AVR and 212 AVR patients finally included in the study and control groups respectively. There were no statistically significant differences between the study groups after PSM in terms of patient demographics and preoperative patient characteristics (Tab. I).

Hospital mortality and predicted mortality were $1.4 \%$ vs. $1.9 \%(p=0.777)$ and $3.2 \pm 1.1 \%$ vs. $3.1 \pm 1.6 \%(p=0.298)$ for RT-AVR vs. AVR groups respectively. Mechanical ventilation time in ICU was $7.3 \pm 3.9 \mathrm{~h}$ for RT-AVR and $9.6 \pm 5.5 \mathrm{~h}$ for AVR patients $(p<0.001)$. More patients in the AVR group required mechanical ventilation for a period of over $24 \mathrm{~h}(7.5 \%$ vs. $2.8 \%, p=0.035)$. Chest tube drainage during the first $24 \mathrm{~h}$ after surgery was $352.7 \pm 249.1 \mathrm{ml}$ in the RT-AVR patients and $523.8 \pm 325.3 \mathrm{ml}$ in AVR patients $(p<0.001)$. The CPB time and aorta cross clamp time were longer for RT-AVR patients (110.8 \pm 25.0 vs. $97.3 \pm 19.1 \mathrm{~min}$, $p<0.001$ and $78.3 \pm 13.5$ vs. $62.9 \pm 13.5 \mathrm{~min}, p<0.001)$. The CPB time longer than 120 min was present in $36.3 \%$ of

Tab. I. Demographic and preoperative characteristics of patients after propensity score matching

\begin{tabular}{|c|c|c|c|c|}
\hline Characteristics & $\begin{array}{l}\text { RT-AVR group } \\
\quad(N=212)\end{array}$ & $\begin{array}{l}\text { AVR group } \\
(N=212)\end{array}$ & $P$-value & $\begin{array}{l}\text { Standardized } \\
\text { differences }\end{array}$ \\
\hline Males, \% (n) & $57.5(122)$ & $54.7(116)$ & 0.565 & 0.057 \\
\hline Age [years] & $68.1 \pm 10.3$ & $68.6 \pm 10.5$ & 0.559 & 0.050 \\
\hline Age > 80 years, $\%(n)$ & $4.7(10)$ & $6.1(13)$ & 0.458 & 0.062 \\
\hline Body mass index $\left[\mathrm{kg} / \mathrm{m}^{2}\right]$ & $27.0 \pm 5.4$ & $27.3 \pm 7.1$ & 0.912 & 0.045 \\
\hline Body mass index $>25 \mathrm{~kg} / \mathrm{m}^{2}, \%(n)$ & $62.7(133)$ & $60.8(129)$ & 0.707 & 0.039 \\
\hline Bicuspid aortic valve, \% ( $n$ ) & $32.5(69)$ & $34.0(72)$ & 0.757 & 0.030 \\
\hline Aortic stenosis, \% ( $n$ ) & $72.2(153)$ & $71.2(151)$ & 0.821 & 0.021 \\
\hline Aortic valve area $\left[\mathrm{cm}^{2}\right]$ & $0.7 \pm 0.4$ & $0.7 \pm 0.3$ & 0.716 & 0.032 \\
\hline $\mathrm{Hb}$ (a day before surgery) [g/dl] & $13.6 \pm 2.7$ & $13.4 \pm 2.9$ & 0.430 & 0.064 \\
\hline Haemodialysis, \% (n) & $0.5(1)$ & $0.9(2)$ & 0.773 & 0.056 \\
\hline Renal insufficiency, \% (n) & $9.9(21)$ & $9.4(20)$ & 0.879 & 0.016 \\
\hline Diabetes, \% (n) & $13.7(29)$ & $15.1(32)$ & 0.666 & 0.040 \\
\hline COPD, \% $(n)$ & $7.5(16)$ & $7.1(15)$ & 0.862 & 0.018 \\
\hline $\mathrm{EF}(\%)$ & $48.6 \pm 12.3$ & $47.7 \pm 14.6$ & 0.304 & 0.065 \\
\hline $\mathrm{EF}>40 \%, \%(n)$ & $76.4(162)$ & $75.0(159)$ & 0.678 & 0.033 \\
\hline Hypertension, \% (n) & $46.2(98)$ & $45.8(97)$ & 0.923 & 0.009 \\
\hline Coronary artery disease, \% (n) & $13.7(29)$ & $12.7(27)$ & 0.773 & 0.028 \\
\hline Peripheral vascular disease, \% ( $n$ ) & $14.6(31)$ & $14.2(30)$ & 0.889 & 0.013 \\
\hline Cerebrovascular disease, \% ( $n$ ) & $10.8(23)$ & $9.9(21)$ & 0.763 & 0.031 \\
\hline History of atrial fibrillation, \% ( $n$ ) & $12.3(26)$ & $10.4(22)$ & 0.522 & 0.059 \\
\hline NYHA class III or IV, \% (n) & $25.9(55)$ & $25.0(53)$ & 0.833 & 0.022 \\
\hline History of myocardial infarction, \% ( $n$ ) & $11.8(25)$ & $10.8(23)$ & 0.768 & 0.030 \\
\hline Predicted mortality, Euro SCORE II, \% & $3.2 \pm 1.1$ & $3.1 \pm 1.6$ & 0.298 & 0.029 \\
\hline
\end{tabular}

Continuous variables are described by mean \pm standard deviation (SD), categorical variables are shown as a percentage, $n$ - number of patients, AVR - aortic valve replacement through sternotomy, COPD - chronic obstructive pulmonary disease, CPB - cardiopulmonary bypass, EF - ejection fraction, EuroSCORE II - European System for Cardiac Operative Risk Evaluation, $\mathrm{Hb}$ - haemoglobin concentration, NYHA - New York Heart Association, RT-AVR - minimally invasive aortic valve replacement through right minithoracotomy. 
Tab. II. Spirometry parameters of patients after minimally invasive and conventional aortic valve replacement

\begin{tabular}{|c|c|c|c|}
\hline Characteristics & $\begin{array}{c}\text { Minimally } \\
\text { invasive } \\
\text { (RT-AVR group) } \\
(N=212)\end{array}$ & $\begin{array}{c}\text { Median } \\
\text { sternotomy } \\
\text { (AVR group) } \\
(N=212)\end{array}$ & $P$-value \\
\hline $\mathrm{FEV}_{1}$ baseline values & $94.7 \pm 9.9$ & $92.8 \pm 14.1$ & 0.361 \\
\hline $\mathrm{FEV}_{1}$ after 1 week & $79.5 \pm 10.1$ & $74.0 \pm 11.3$ & $<0.001$ \\
\hline $\mathrm{FEV}_{1}$ after 1 month & $83.5 \pm 8.6$ & $80.8 \pm 11.1$ & 0.015 \\
\hline $\mathrm{FEV}_{1}$ after 3 months & $84.3 \pm 8.5$ & $83.1 \pm 8.1$ & 0.203 \\
\hline VC baseline values & $95.9 \pm 10.9$ & $91.9 \pm 16.3$ & 0.082 \\
\hline VC after 1 week & $64.8 \pm 8.8$ & $51.5 \pm 11.1$ & $<0.001$ \\
\hline VC after 1 month & $84.2 \pm 9.1$ & $78.6 \pm 10.5$ & $<0.001$ \\
\hline VC after 3 months & $87.2 \pm 7.9$ & $86.2 \pm 8.2$ & 0.110 \\
\hline TLC baseline values & $94.1 \pm 12.9$ & $89.9 \pm 13.2$ & 0.218 \\
\hline TLC after 1 week & $67.1 \pm 7.5$ & $53.3 \pm 13.0$ & $<0.001$ \\
\hline TLC after 1 month & $85.6 \pm 9.1$ & $74.5 \pm 13.7$ & $<0.001$ \\
\hline TLC after 3 months & $86.6 \pm 8.5$ & $86.1 \pm 8.6$ & 0.869 \\
\hline
\end{tabular}

Baseline values of all patients are presented as a percentage of predicted values and expressed as mean \pm standard deviation. Follow-up data are presented as a percentage of preoperative values and expressed as mean \pm standard deviation. $N$ - number of patients, RT-AVR - minimally invasive aortic valve replacement through right minithoracotomy, AVR - aortic valve replacement through median sternotomy, $\mathrm{VC}$ - vital capacity, $\mathrm{FEV}_{1}$ - forced expiratory volume in the first second, TLC - total lung capacity.

Tab. III. Multivariable median regression analysis of forced expiratory volume in the first second changes that occurred 1 week and 3 months after surgery

\begin{tabular}{|c|c|c|c|}
\hline Parameter & $\begin{array}{l}\text { Regression } \\
\text { coefficient }\end{array}$ & $95 \% \mathrm{Cl}$ & $P$-value \\
\hline \multicolumn{4}{|l|}{$\mathrm{FEV}_{1}$ after 1 week: } \\
\hline RT-AVR group & 5.0 & $2.6 ; 7.4$ & $<0.001$ \\
\hline Female sex & 0.0 & $-2.0 ; 2.0$ & 1.000 \\
\hline Age & 0.0 & $-0.7 ; 0.7$ & 1.000 \\
\hline COPD & -14.0 & $-18.4 ;-9.6$ & $<0.001$ \\
\hline $\begin{array}{l}\text { Prolonged CPB time } \\
(>120 \mathrm{~min})\end{array}$ & -1.0 & $-4.1 ; 2.1$ & 0.529 \\
\hline \multicolumn{4}{|l|}{$\mathrm{FEV}_{1}$ after 3 months: } \\
\hline RT-AVR group & 0.2 & $-1.9 ; 2.2$ & 0.872 \\
\hline Female sex & 0.1 & $-2.0 ; 2.1$ & 0.937 \\
\hline Age & -0.8 & $-1.9 ; 0.2$ & 0.113 \\
\hline COPD & -10.4 & $-16.6 ;-4.3$ & 0.001 \\
\hline $\begin{array}{l}\text { Prolonged CPB time } \\
(>120 \mathrm{~min})\end{array}$ & -0.3 & $-3.1 ; 2.5$ & 0.815 \\
\hline
\end{tabular}

COPD - chronic obstructive pulmonary disease, CPB - cardiopulmonary bypass, $\mathrm{FEV}_{1}$ - forced expiratory volume in the first second, RT-AVR - minimally invasive aortic valve replacement through right minithoracotomy.

RT-AVR and $8.5 \%$ of AVR patients ( $p<0.001)$. The ICU and hospital stays were $1.3 \pm 1.2$ vs. $2.6 \pm 2.8$ days $(p<0.001)$ and $5.7 \pm 1.6$ vs. $8.5 \pm 4.3$ days ( $p<0.001)$ in RT-AVR vs. AVR patients respectively.

There was no difference in mean values of baseline spirometry parameters expressed as percentage of predicted values between groups. One week and 1 month after sur- gery, all spirometry parameters were reduced in comparison to the baseline values in both RT-AVR and AVR groups. The pulmonary function test results were statistically significantly higher in the RT-AVR group than the AVR group.

Three months after surgery, all spirometry parameters were still reduced and had not returned to preoperative values in either the RT-AVR or AVR group. However, the difference in spirometry values was no longer statistically significant between RT-AVR and AVR groups (Tab. II).

The linear median regression model shows that the surgical technique used for the RT-AVR group was associated with higher values of spirometry parameters obtained 1 week after surgery. The regression coefficient for the RT-AVR surgical technique in the model describing the change of $\mathrm{FEV}_{1} 1$ week after surgery was $5.0(p<0.001)$, which means that the $\mathrm{FEV}_{1}$ median value was 5.0 percentage points higher in the RT-AVR group after adjusting for sex, age, presence of COPD and prolonged CPB time. Three months after surgery, these results were no longer present. Presence of COPD was associated with lower values of spirometry parameters after surgery (Tab. III).

\section{Discussion}

The main findings of our study were that the respiratory function was more impaired in the sternotomy group, and there was a statistically significant difference in the pulmonary status of the two groups 1 week after surgery. This would suggest that faster mobilisation and more efficient early recovery of pulmonary function are more likely for patients who have had minimally invasive RT-AVR surgery [3].

Other studies previously showed that less invasive surgical approaches to cardiac surgery have advantages over the standard median sternotomy in terms of postoperative pulmonary function and the recovery of pulmonary status $[2,3]$. These reports presented similar results to our study. The patients who underwent RT-AVR surgery had less impaired postoperative respiratory function. This was probably due to their chest wall integrity being better preserved in comparison to patients who undergo a median sternotomy $[3,4]$.

According to our observations, more invasive surgery through a standard median sternotomy resulted in longer mechanical ventilation time than with a right minithoracotomy. Therefore, the ICU and hospital stay was significantly shorter in RT-AVR patients [9].

As could be expected, the pulmonary functional status indicated by spirometry examinations continued to improve steadily over the postoperative months [10]. The difference in pulmonary function between the groups disappeared between 1 and 3 months after the operation, and it can be assumed that in the later postoperative period pulmonary rehabilitation would be comparable in both the RT-AVR and AVR groups. Nevertheless, for as long as 3 months after surgery, neither the AVR nor the RT-AVR spirometry parameters returned to preoperative values. This demonstrates that the results of surgical trauma can impair pulmonary function for a significant length of time after surgery. 
Using a minithoracotomy for surgical access makes the surgery more demanding, as the small thoracic working port results in more difficulties at every step of the aortic valve replacement procedure. This all requires additional time, which translates into longer aortic cross-clamping time and operation time. This observation confirms previous reports on minimally invasive heart valve surgery [11].

In our model of multivariable median regression analysis, minimally invasive RT-AVR surgery was a factor that had a strong influence on obtaining better spirometry parameters values early after surgery.

The minimally invasive RT-AVR surgery resulted in shorter ventilation time in ICU and less respiratory failure expressed by reduced incidence of prolonged mechanical ventilation time.

In the RT-AVR group, there was no instance of mediastinitis, but $2.8 \%$ of patients from the AVR group had mediastinitis and sternum instability requiring surgical treatment.

Postoperative chest tube drainage in patients undergoing RT-AVR was also statistically significantly lower. This could be a reflection of the reduced surgical trauma from a minithoracotomy compared to median sternotomy surgery [9-11]. Further studies should be continued to explain the relation between the extent of surgical trauma after cardiac surgical procedures and postoperative function of the respiratory system.

\section{Limitations}

There are several limitations of our study. The first is that it was not randomized, but a single-centre observational study, and thus the results we obtained should be explored further. Higher risk patients were excluded from the analysis, as in our department these patients are preferentially operated on with a conventional median sternotomy approach.

Secondly, the functional pulmonary status evaluation with spirometry examination was discontinued 3 months after surgery.

Finally, we did not perform postoperative pain analysis, which is an important factor that could have an influence on postoperative recovery and pulmonary functional status. Standardized postoperative pain evaluation was not included in the postoperative care protocol in our institution. Our subjective experience was that pain control following our protocol was equally efficient for both the conventional AVR and minimally invasive RT-AVR groups.

\section{Conclusions}

To summarize, we can conclude that the less invasive, RT-AVR surgery is a safe procedure, which allows for a reduction in surgical trauma and positively influences pulmonary recovery especially in the early postoperative period, which leads to shortened ICU and hospital stays. In our personal opinion, it is justifiable to state that minimally invasive RT-AVR surgery could potentially be a better option for patients who have previously suffered from pulmonary disease (such as chronic obstructive pulmonary disease) and who are at higher risk of developing pulmonary dysfunction.

\section{Disclosure}

The authors report no conflict of interest.

\section{References}

1. Glauber M, Miceli A, Bevilacqua S, Farneti PA. Minimally invasive aortic valve replacement via right anterior minithoracotomy: early outcomes and midterm follow-up. J Thorac Cardiovasc Surg 2011; 142: 1577-1579.

2. Bonacchi M, Prifti E, Giunti G, Salica A, Frati G, Sani G. Respiratory dysfunction after coronary artery bypass grafting employing bilateral internal mammary arteries: the influence of intact pleura. Eur J Cardiothorac Surg 2001; 19: 827-833.

3. Silva AM, Saad R, Stirbulov R, Rivetti LA. Off-pump versus on-pump coronary artery revascularization: effects on pulmonary function. Interact Cardiovasc Thorac Surg 2010; 11: 42-45.

4. Von Elm E, Altman DG, Egger M, Pocock SJ, Gøtzsche PC, Vandenbroucke JP; STROBE Initiative. The strengthening the reporting of observational studies in epidemiology (STROBE) statement: guidelines for reporting observational studies. PLoS Med 2007; 4: e296.

5. Gajic O, Malinchoc M, Comfere TB, Harris MR, Achouiti A, Yilmaz M, Schultz MJ, Hubmayr RD, Afessa B, Farmer JC. The stability and workload index for transfer score predicts unplanned intensive care unit patient readmission: initial development and validation. Crit Care Med 2008; 36: 676-682.

6. Plass A, Scheffel H, Alkadhi H, Kaufmann P, Genoni M, Falk V, Grunenfelder J. Aortic valve replacement through a minimally invasive approach: preoperative planning, surgical technique, and outcome. Ann Thorac Surg 2009; 88: 1851-1856.

7. Koenker R. Quantile Regression. Cambridge University Press, Cambridge 2005.

8. R Development Core Team (2010). R: A language and environment for statistical computing. R Foundation for Statistical Computing, Vienna, Austria. ISBN 3-900051-07-0, http://www.R-project.org (accessed 11 May 2016. R Development Core Team (2010). R: A language and environment for sta-istical computing. R Foundation for Statistical Computing, Vienna, Austria. ISBN 3-900051-07-0, http://www.R-project.org (accessed 11 May 2016).

9. Gilmanov D, Bevilacqua S, Murzi M, Cerillo AG, Gasbarri T, Kallushi E, Miceli A, Glauber M. Minimally invasive and conventional aortic valve replacement: a propensity score analysis. Ann Thorac Surg 2013; 96: 837-843.

10. Lamelas J, Nguyen TC. Minimally invasive valve surgery: when less is more. Semin Thorac Cardiovasc Surg 2015; 271: 49-56.

11. Merk DR, Lehmann S, Holzhey DM, Dohmen P, Candolfi P, Misfeld M, Mohr FW, Borger MA. Minimal invasive aortic valve replacement surgery is associated with improved survival: a propensity-matched comparison. Eur J Cardiothorac Surg 2015; 47: 11-17. 